\title{
Correction to: Durability properties of high volume fly ash concrete containing nano-silica
}

\author{
Steve Wilben Macquarie Supit • Faiz Uddin Ahmed Shaikh
}

Accepted: 17 September 2021 / Published online: 1 December 2021

(C) RILEM 2021

\section{Correction to:}

Materials and Structures (2015) 48:2431-2445 https://doi.org/10.1617/s11527-014-0329-0

The authors regret that they forgot to cite the following citation in the caption of Figure 11 in this paper:

[45] Shaikh FUA, Supit SWM, Sarker PK (2014) A study on the effect of nano silica on compressive strength of high volume fly ash mortars and concretes. Mater Des 60:433-442

The authors would like to apologise for any inconvenience caused.

Publisher's Note Springer Nature remains neutral with regard to jurisdictional claims in published maps and institutional affiliations.

The original article can be found online at https:// doi.org/10.1617/s11527-014-0329-0.

S. W. M. Supit · F. U. A. Shaikh $(\bowtie)$

Department of Civil Engineering, Curtin University,

Perth, WA, Australia

e-mail: shaikhfa@rocketmail.com;

s.ahmed@curtin.edu.au 